ORNL/TM-12860

FECEIVED

JUL 181995

OSTI

OAK RIDGE

NATIONAL

LABORATORY

\title{
ENVIRONMENTAL RESOURCES OF SELECTED AREAS OF HAWAII:
}

MARTIN MARUETRA

\section{SOCIOECONOMICS}

\author{
by \\ James W. Saulsbury, \\ Barbara M. Sorensen, and \\ Susan M. Schexnayder \\ Robert M. Reed, \\ Project Manager
}

MANAGED BY

MARTIN MARIETTA ENERGY SYSTEMS, INC.

- FOR THE UNITED STATES -

DEPARTMENT OF ENERGY 
This report has been reproduced directly from the best available copy.

Available to DOE and DOE contractors from the Office of Scientific and Technical Information, P.O. Box 62, Oak Ridge, TN 37831; prices available from (615) 576-8401, FTS 626-8401.

Available to the public from the National Technical Information Service, U.S. Department of Commerce, 5285 Port Royal Rd., Springfield, VA 22161.

This report was prepared as an account of work sponsored by an agency of the United States Government. Neither the United States Government nor any agency thereof, nor any of their employees, makes any warranty, express or implied, or assumes any legal liability or responsibility for the accuracy, completeness, or usefulness of any information, apparatus, product, or process disclosed, or represents that its use would not infringe privately owned rights. Reference herein to any specific commercial product, process, or service by trade name, trademark, manufacturer, or otherwise, does not necessarily constitute or imply its endorsement, recommendation, or favoring by the United States Government or any agency thereof. The views and opinions of authors expressed herein do not necessarily state or reflect those of the United States Government or any agency thereof. 


\section{DISCLAIMER}

Portions of this document may be illegible in electronic image products. Images are produced from the best available original document. 


\title{
ENVIRONMENTAL RESOURCES OF SELECTED AREAS OF HAWAII: SOCIOECONOMICS
}

\author{
James W. Saulsbury \\ Barbara M. Sorensen \\ Susan M. Schexnayder ${ }^{1}$ \\ Robert M. Reed, Project Manager \\ Energy Division
}

March 1995

$\overline{{ }^{1} \text { University of Tennessee }}$

Prepared for

U.S. Department of Energy

Oak Ridge Operations Office

\author{
by \\ OAK RIDGE NATIONAL LABORATORY \\ Oak Ridge, Tennessee 37831 \\ managed by \\ MARTIN MARIETTA ENERGY SYSTEMS, INC. \\ for the \\ U.S. DEPARTMENT OF ENERGY \\ under contract DE-AC05-84OR21400
}


[Blank Page] 


\section{CONTENTS}

LIST OF FIGURES $\ldots \ldots \ldots \ldots \ldots \ldots \ldots \ldots \ldots \ldots \ldots \ldots \ldots \ldots \ldots \ldots$

LIST OF TABLES $\ldots \ldots \ldots \ldots \ldots \ldots \ldots \ldots \ldots \ldots \ldots \ldots \ldots \ldots \ldots \ldots \ldots \ldots \ldots \ldots \ldots \ldots$

ACRONYMS AND ABBREVIATIONS $\ldots \ldots \ldots \ldots \ldots \ldots \ldots \ldots \ldots \ldots \ldots \ldots \ldots$ ix

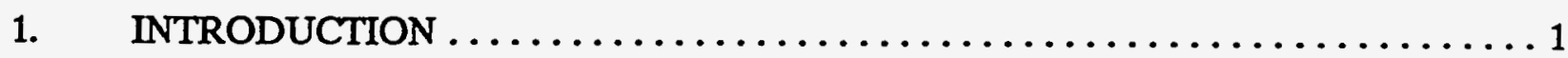

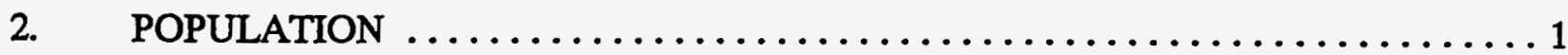

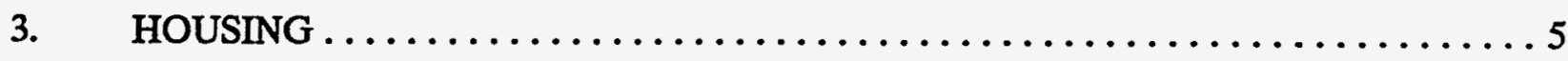

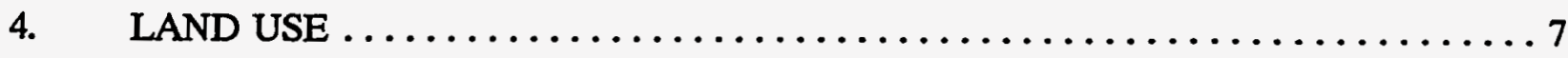

5. ECONOMIC STRUCTURE $\ldots \ldots \ldots \ldots \ldots \ldots \ldots \ldots \ldots \ldots \ldots \ldots \ldots$

6. INFRASTRUCTURE AND PUBLIC SERVICE $\ldots \ldots \ldots \ldots \ldots \ldots \ldots \ldots \ldots \ldots$

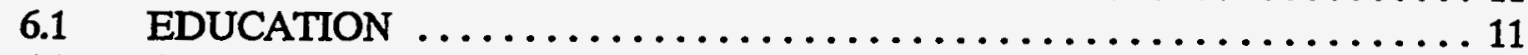

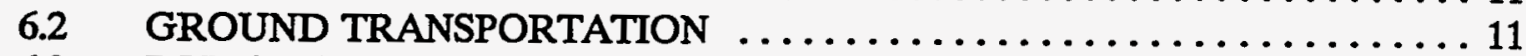

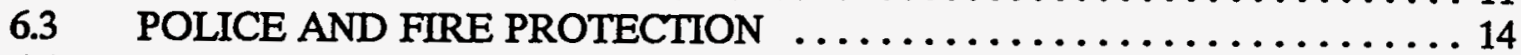

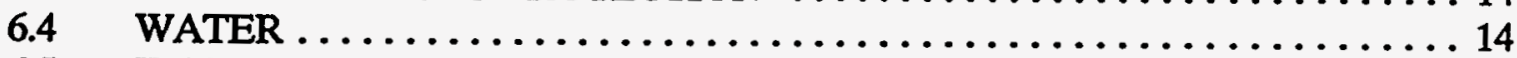

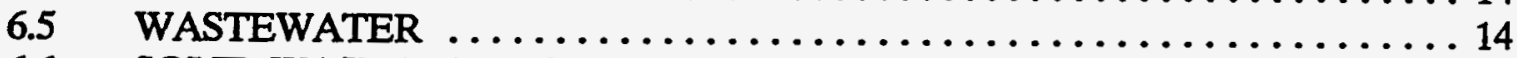

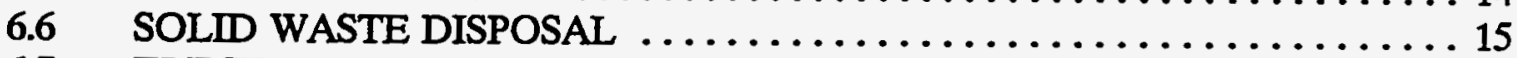

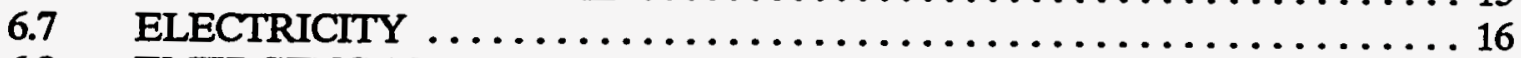

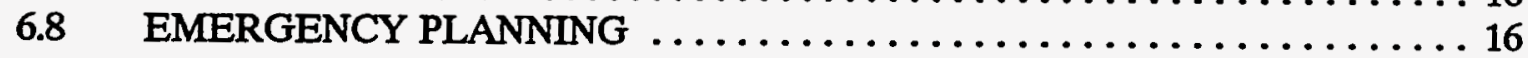

7. LOCAL GOVERNMENT REVENUES AND EXPENDITURES $\ldots \ldots \ldots \ldots \ldots 18$

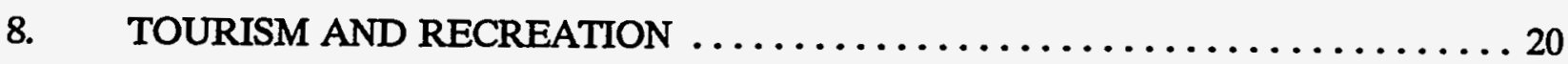

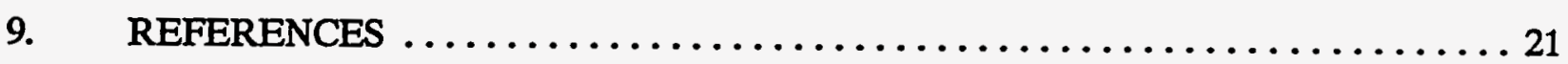

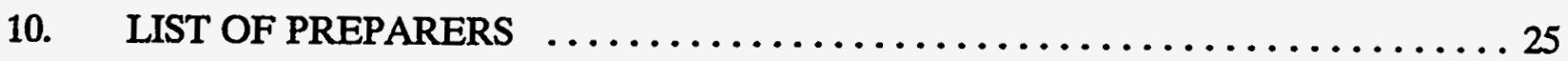


[blank page] 


\section{LIST OF FIGURES}

Figure $\quad \underline{\text { Page }}$

1 Hawaii County: Census districts and principal towns $\ldots \ldots \ldots \ldots \ldots \ldots \ldots \ldots \ldots \ldots \ldots$

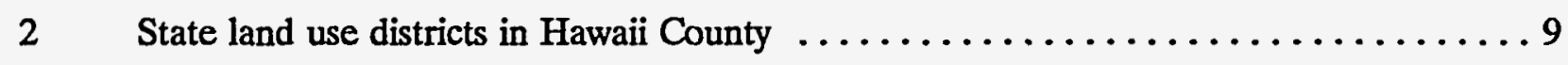

3 Hawaii County: Major road segments $\ldots \ldots \ldots \ldots \ldots \ldots \ldots \ldots \ldots \ldots \ldots \ldots \ldots \ldots \ldots \ldots$ 
[blank page] 


\section{LIST OF TABLES}

Table

Page

1 Resident population and population growth in the state and county of Hawaii ...... 3

2 De facto population in the State and County of Hawaii $\ldots \ldots \ldots \ldots \ldots \ldots$

3 Resident population projections for the State and County of Hawaii: 1995-2010 . . . . . 4

4 De facto population projections for the State and County of Hawaii: 1995-2010 . . . . . 4

5 Trends in resident population by Census Districts, Hawaii County: 1970, 1980,

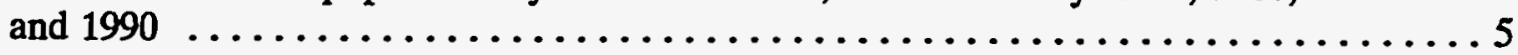

6 Housing availability in Hawaii County and the Puna District (1990) . . . . . . . . 6

7 Median housing values and contract rents for the state and county of Hawaii ...... 7

8 Visitor accommodations in Hawaii County $\ldots \ldots \ldots \ldots \ldots \ldots \ldots \ldots \ldots \ldots$

9 Distribution of total acreage within each land use district: State of Hawaii, Hawaii

County, and the Puna District $\ldots \ldots \ldots \ldots \ldots \ldots \ldots \ldots \ldots \ldots \ldots \ldots$

10 Land use by acreage and as a percentage of total: Hawaii County and the Puna District ....................................... 10

11 Public school enrollment, capacity, and projected enrollment in the Puna area ...... 12

12 County of Hawaii Department of Water Supply systems in the Puna District ....... 15

13 Hawaii County operating revenues and expenditures, FY $1990 \ldots \ldots$. . . . . . . . . 19 
[blank page]

viii 


\section{ACRONYMS AND ABBREVIATIONS}

$\begin{array}{ll}\text { DOE } & \text { U.S. Department of Energy } \\ \text { EIS } & \text { Environmental Impact Statement } \\ \text { Fed. Regis. } & \text { Federal Register } \\ \text { ft } & \text { foot } \\ \text { FY } & \text { fiscal year } \\ \text { gal } & \text { gallon } \\ \text { ha } & \text { hectare } \\ \text { HCCDA } & \text { Hawaii County Civil Defense Agency } \\ \text { HGP } & \text { Hawaii Geothermal Project } \\ \text { km } & \text { kilometer } \\ \text { kWh } & \text { kilowatt-hour } \\ \text { L } & \text { liter } \\ \text { LEPC } & \text { local emergency planning committee } \\ \text { LOS } & \text { level of service } \\ \text { m } & \text { meter } \\ \text { mg } & \text { milligram } \\ \text { Mgd } & \text { million gallons per day } \\ \text { SERC } & \text { State Emergency Response Commission } \\ \text { SOH } & \text { Scientific Observation Hole }\end{array}$




\section{[blank page]}




\section{INTRODUCTION}

This report has been prepared to make available and archive the background information on socioeconomic resources collected during the preparation of the environmental impact statement (EIS) for Phases 3 and 4 of the Hawaii Geothermal Project (HGP) as defined by the state of Hawaii in its April 1989 proposal to Congress. The U.S. Department of Energy (DOE) published a notice in the Federal Register on May 17, 1994 (Fed. Regis. 59, 25638), withdrawing its Notice of Intent (Fed. Regis. 57, 5433), of February 14, 1992, to prepare the HGP EIS. Since the state of Hawaii is no longer pursuing or planning to pursue the HGP, DOE considers the project to be terminated.

This document provides background information on socioeconomic resources in Hawaii County, with particular emphasis on the Puna District (Fig. 1). Information is being made available for use by others in conducting future socioeconomic impact assessments in this area. This report describes existing socioeconomic resources in the areas studied (i.e., the affected environment) and does not represent an assessment of environmental impacts. The socioeconomic resources described are primarily those that would be affected by employment and population growth associated with any future large-scale development. These resource categories are (1) population, (2) housing, (3) land use, (4) economic structure (primarily employment and income), (5) infrastructure and public services (education, ground transportation, police and fire protection, water, wastewater, solid waste disposal, electricity, and emergency planning), (6) local government revenues and expenditures, and (7) tourism and recreation.

\section{POPULATION}

Hawaii County, which had a 1990 resident population of 120,317, is the second most populous county in the state (U.S. Bureau of the Census 1992). Although the county's population growth rate has exceeded growth rates for the state and for the city and county of Honolulu since 1970 (Table 1), Hawaii County accounts for only $10 \%$ of the state's resident population.

Because there are large numbers of tourists in the state throughout the year, resident population statistics do not account for all the individuals who require housing, goods, and services. Thus, the state tallies a de facto population total that includes visitors but excludes residents who are temporarily absent (DBEDT 1991a). In the last two decades, the state's de facto population has increased considerably relative to its resident population due to increases in tourism (Table 2).

Resident and de facto population projections are presented in Tables 3 and 4, respectively. Hawaii County is expected to lead the state in resident population growth during the next two decades. Only Kauai County is expected to grow faster than Hawaii County in terms of de facto population (County of Hawaii 1991). In general, de facto population growth is expected to exceed resident population growth for all Hawaiian counties (County of Hawaii 1991). 


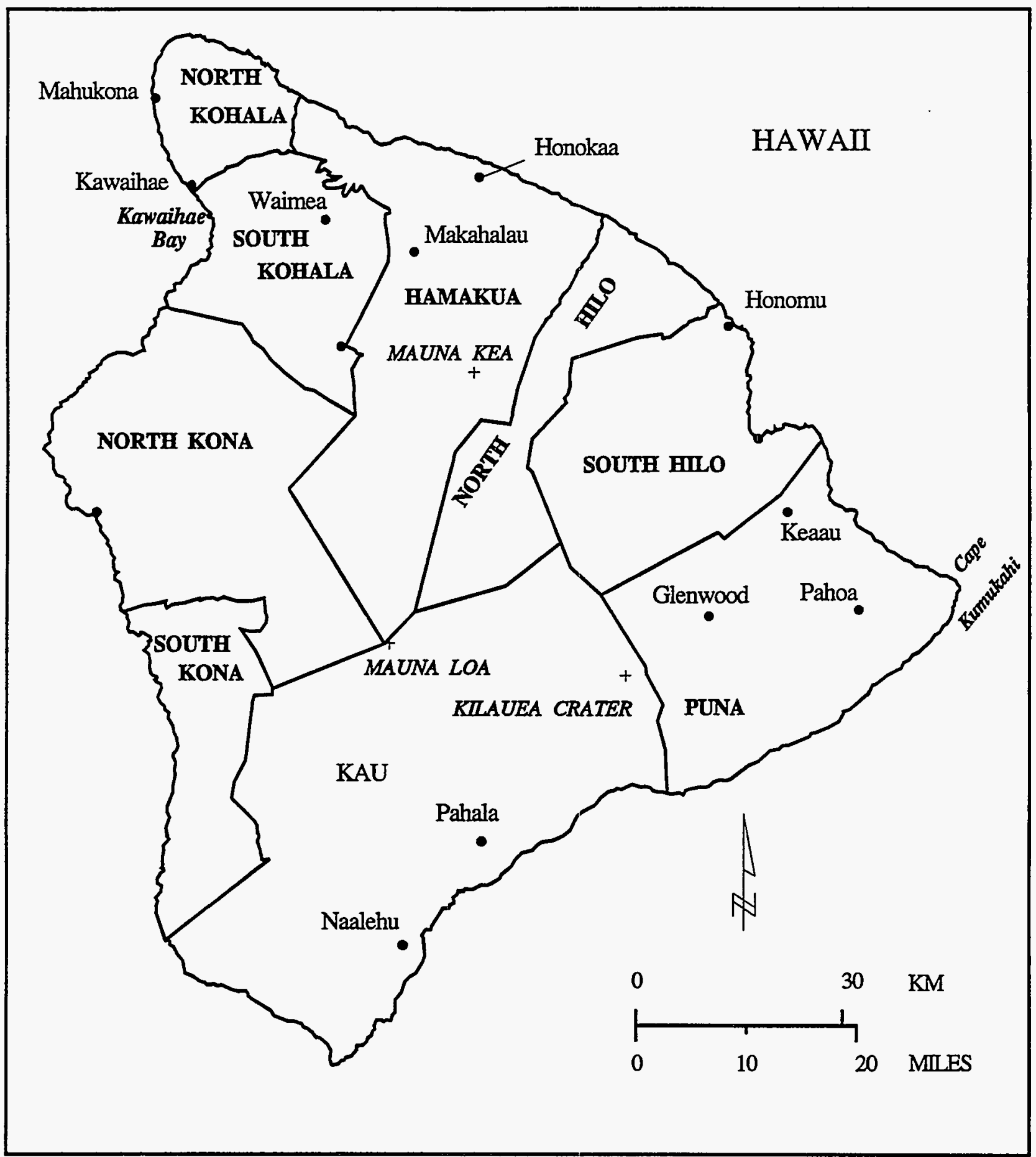

Fig. 1. Hawaii County: Census districts and principal towns. Source: Developed using information from the Hawaii Office of State Planning Geographic Information System. 
Table 1. Resident population and population growth in the state and county of Hawaii

\begin{tabular}{lrrr|||cc}
\hline & \multicolumn{3}{c||}{} & \multicolumn{2}{c}{$\begin{array}{c}\text { Growth rate } \\
(\%)\end{array}$} \\
\cline { 2 - 6 } Place & \multicolumn{1}{c||}{ Population } & \multicolumn{1}{c|}{1990} & $1970-80$ & $1980-90$ \\
\hline State of Hawaii & 769,913 & 964,691 & $1,108,229$ & 25.3 & 14.9 \\
Hawaii County & 63,468 & 92,053 & 120,317 & 45.0 & 30.7 \\
\hline
\end{tabular}

Sources: U.S. Bureau of the Census 1978, 1988, 1992.

Table 2. De facto population in the state and county of Hawaii

\begin{tabular}{lrrr||crr}
\hline & \multicolumn{3}{c||}{ Population } & \multicolumn{3}{c}{ \% larger than resident population } \\
\cline { 2 - 6 } Place & 1970 & 1980 & 1990 & 1970 & 1980 & 1990 \\
\hline State of Hawaii & 796,500 & $1,052,700$ & $1,248,400$ & 3.4 & 9.1 & 12.6 \\
Hawaii County & 65,700 & 98,700 & 135,100 & 3.5 & 7.2 & 12.3 \\
\hline
\end{tabular}

Note: The de facto population is defined as the number of persons physically present in an area, regardless of military status or usual place of residence. It includes visitors present, but excludes residents temporarily absent.

Sources: County of Hawaii 1991; U.S. Bureau of the Census 1978, 1988, 1992.

Much of Hawaii County's population is concentrated along its coastal areas. Hilo (1990 resident population of 37,808 ) is the largest urban area in the county, but has experienced little growth in the past two decades relative to other areas of the island. One of the fastest growing areas in the county has been the Puna District $(20,781)$, which experienced growth rates of $128 \%$ and 76.8\% during the periods 1970-1980 and 1980-1990, respectively (Table 5). Within the Puna District, growth has occurred primarily in the central subdivisions, as population centers have shifted away from older towns such as Volcano (1516), Pahoa (1020), and Kurtistown (910) (County of Hawaii 1992a; DBEDT 1993). 
Table 3. Resident population projections for the state and county of Hawaii: 1995-2010

\begin{tabular}{lcccc||cc}
\hline & \multicolumn{4}{c||}{$\begin{array}{c}\text { Population } \\
\text { (in thousands) }\end{array}$} & \multicolumn{2}{c}{$\begin{array}{c}\text { Growth rate } \\
\text { (\%) }\end{array}$} \\
\cline { 2 - 7 } & 1995 & 2000 & 2005 & 2010 & $1990-2000$ & $2000-2010$ \\
\hline $\begin{array}{l}\text { State of } \\
\text { Hawaii }\end{array}$ & 1225 & 1285 & 1350 & 1435 & 15.6 & 11.7 \\
$\begin{array}{l}\text { Hawaii } \\
\text { County }\end{array}$ & 142 & 160 & 180 & 206 & 32.6 & 28.5 \\
\hline
\end{tabular}

Note: The resident population is defined as the number of persons whose usual place of residence is in an area, regardless of physical location on the census date.

Sources: County of Hawaii 1991, 1988.

Table 4. De facto population projections for the state and county of Hawaii: 1995-2010

\begin{tabular}{|c|c|c|c|c|c|c|}
\hline \multirow[t]{2}{*}{ Place } & \multicolumn{4}{|c|}{$\begin{array}{l}\text { Population } \\
\text { (in thousands) }\end{array}$} & \multicolumn{2}{|c|}{$\begin{array}{c}\text { Growth rate } \\
(\%)\end{array}$} \\
\hline & 1995 & 2000 & 2005 & 2010 & $1990-2000$ & 2000-2010 \\
\hline $\begin{array}{l}\text { State of } \\
\text { Hawaii }\end{array}$ & 1382 & 1468 & 1560 & 1674 & 16.9 & 14.0 \\
\hline $\begin{array}{l}\text { Hawaii } \\
\text { County }\end{array}$ & 158 & 183 & 211 & 243 & 34.6 & 32.8 \\
\hline
\end{tabular}

Note: See note to Table 2.

Sources: County of Hawaii 1991, 1988. 
Table 5. Trends in resident population by census districts, Hawaii County: 1970, 1980, and 1990

\begin{tabular}{lrrr||rr}
\hline & \multicolumn{3}{c||}{ Population } & \multicolumn{2}{c}{$\begin{array}{c}\text { Growth rate } \\
\text { (\%) }\end{array}$} \\
\cline { 2 - 5 } District & \multicolumn{1}{c}{1970} & 1980 & 1990 & $1970-80$ & $1980-90$ \\
\hline Hawaii County & 63,468 & 92,053 & 120,317 & 45.0 & 30.7 \\
Puna & 5,154 & 11,751 & 20,781 & 128.0 & 76.8 \\
South Hilo & 33,915 & 42,278 & 44,639 & 24.7 & 5.6 \\
North Hilo & 1,881 & 1,679 & 1,541 & -10.7 & -8.2 \\
Hamakua & 4,648 & 5,128 & 5,545 & 10.3 & 8.1 \\
North Kohala & 3,326 & 3,249 & 4,291 & -2.3 & 32.1 \\
South Kohala & 2,310 & 4,607 & 9,140 & 99.4 & 98.4 \\
North Kona & 4,832 & 13,748 & 22,284 & 184.5 & 62.1 \\
South Kona & 4,004 & 5,914 & 7,658 & 47.7 & 29.5 \\
Kau & 3,398 & 3,699 & 4,438 & 8.9 & 20.0 \\
\hline
\end{tabular}

Source: County of Hawaii 1991.

\section{HOUSING}

During the last two decades, the housing supply in Hawaii County has increased substantially to accommodate growth in the resident and tourist populations. The number of housing units in Hawaii County increased $80.7 \%$ between 1970 and 1980, and $26.4 \%$ between 1980 and 1990 (U.S. Bureau of the Census 1978, 1988, 1992). In 1990, the county had 48,253 housing units; $53 \%$ were owner-occupied, $33 \%$ renter-occupied, and $14 \%$ vacant (Table 6). Fiftyeight percent of the housing units in Hawaii County are located on the eastern end of the island in the South Hilo and Puna Districts.

Vacant housing units in Hawaii County include units held for seasonal or recreational use, a category that accounts for nearly $5 \%$ of the total housing stock (Table 6). More than $60 \%$ of these seasonal/recreational units are located on the western side of the island, particularly in the North Kona and South Kohala Districts. Rental vacancy rates are much higher on the western side of the island than on the eastern side, where vacancy rates in Hilo and Pahoa are $6.7 \%$ and 
Table 6. Housing availability in Hawaii County and the Puna District, 1990 (number of units)

\begin{tabular}{|c|c|c|c|c|c|c|}
\hline \multirow[b]{2}{*}{ District and division } & \multirow[b]{2}{*}{$\begin{array}{l}\text { Total } \\
\text { units }\end{array}$} & \multirow[b]{2}{*}{$\begin{array}{c}\text { Renter } \\
\text { occupied }\end{array}$} & \multicolumn{4}{|c|}{ Vacant housing units } \\
\hline & & & $\begin{array}{c}\text { Total } \\
\text { vacant }\end{array}$ & $\begin{array}{l}\text { Seasonal, } \\
\text { rec., or } \\
\text { occasional } \\
\text { use }\end{array}$ & $\begin{array}{l}\text { Home- } \\
\text { owner } \\
\text { vacancy } \\
\text { rate }(\%)\end{array}$ & $\begin{array}{c}\text { Rental } \\
\text { vacancy } \\
\text { rate }(\%)\end{array}$ \\
\hline Hawaii County & 48,253 & 16,125 & 6,792 & 2,045 & 1.5 & 10.3 \\
\hline Puna & 8,597 & 2,058 & 1,461 & 369 & NA & NA \\
\hline Pahoa-Kalapana & 2,722 & 702 & 451 & 135 & 2.4 & 8.4 \\
\hline Keaau-Mtn. View & 5,875 & 1,356 & 1,010 & 244 & 2.3 & 7.1 \\
\hline
\end{tabular}

Source: County of Hawaii 1991.

$8.4 \%$, respectively. Homeowner vacancy rates vary slightly throughout the county but are generally low. Median housing values and contract rents in Hawaii County are considerably lower than elsewhere in the state (Table 7) (County of Hawaii 1991). In the Puna District, approximately one-half of the housing units are less than 10 years old. Puna's housing growth-like population growth-is occurring in the central subdivisions rather than in the older towns. Four subdivisions accounted for 55\% of the building permits issued in 1990; two of the subdivisions, Hawaiian Paradise Park and Hawaiian Beaches, accounted for over $40 \%$ of the permits (County of Hawaii 1992a).

Housing values are lower in the Puna District than in other parts of Hawaii Countyprobably because of the decreasing value of older housing in Volcano, Pahoa, and Kurtistown and because of a lack of utilities, including grid electricity in approximately $27 \%$ of the housing units and plumbing in $7 \%$ of the units (County of Hawaii 1992a). Median contract rents in the Puna District (approximately \$415) are slightly lower than in the county as a whole (County of Hawaii 1991).

In addition to standard residential units, Hawaii County has numerous visitor accommodations. Table 8 provides information about the number, availability, and costs of visitor units on the island. At least half of the almost 9000 units are located on the western side of the island in and around the North Kona District. 
Table 7. Median housing values and contract rents for the state and county of Hawaii

\begin{tabular}{lcc}
\hline $\begin{array}{l}\text { District and } \\
\text { division }\end{array}$ & $\begin{array}{c}\text { Median } \\
\text { housing value }\end{array}$ & $\begin{array}{c}\text { Median monthly } \\
\text { contract rent }\end{array}$ \\
\hline State of Hawaii & $\$ 245,300$ & $\$ 599$ \\
Hawaii County & 113,000 & 428 \\
Puna & NA & 415 \\
Pahoa-Kalapana & 68,300 & 419 \\
Keaau-Mountain View & 76,400 & 409 \\
\hline
\end{tabular}

Source: County of Hawaii 1991.

Table 8. Visitor accommodations in Hawaii County, 1990

\begin{tabular}{lccccc}
\hline Place & No. of units & $\begin{array}{c}\text { Units } \\
\text { excluding } \\
\text { condos }^{a}\end{array}$ & $\begin{array}{c}\text { Av. } \\
\text { occupancy } \\
\text { rate }(\%)\end{array}$ & $\begin{array}{c}\text { Av. room } \\
\text { rate (\$) }\end{array}$ & $\begin{array}{c}\text { Av. guest } \\
\text { rate (\$) }\end{array}$ \\
\hline Hawaii County & 8,952 & 6,837 & 62.0 & 125.31 & 60.58 \\
$\begin{array}{l}\text { Hawaii County } \\
\text { excluding Kona } \\
\text { area }^{b}\end{array}$ & 4,856 & 4,275 & 59.3 & NA & NA \\
\hline
\end{tabular}

ancludes hotels, apartment/hotels, motels, cottages, and bed and breakfasts excludes; condominiums and condominium/hotel accommodations in rental pools for transient use (time-shares).

${ }^{b}$ Hawaii County data excluding the Kona area are presented because accommodations in Kona are well beyond a 1-b commuting range from the Puna District. Some accommodations in other areas may also be beyond commuting range but are included because separate data are not available.

Source: County of Hawaii 1991.

\section{LAND USE}

Under Hawaii's state land use law, all land is classified in one of four land use districts: urban, rural, agricultural, or conservation. Urban districts include lands characterized by urban 
concentrations of people, structures, and services and vacant areas designated for future development. Rural districts include small farms intermixed with low-density residential lots. Agricultural districts include lands for the cultivation of crops, aquaculture, raising livestock, windfarming, forestry, agricultural-support activities, open-area recreational use, and lands with significant potential for agricultural use. Conservation districts are comprised primarily of lands in existing forest and water reserve zones, and include areas necessary for protecting watersheds and water sources, scenic and historic areas, parks, wilderness, open space, recreational areas, habitats for endemic plants, fish and wildlife, and all submerged lands seaward of the shoreline (Land Use Commission 1991).

Approximately $66 \%$ of the state's conservation land is located in Hawaii County (Land Use Commission 1991). Table 9 compares land classification percentages for the state with those for Hawaii County and the Puna District. Figure 2 shows state-designated land use district boundaries for Hawaii County. These districts accurately reflect the three primary land uses in

Table 9. Distribution of total acreage within each land use district: State of Hawaii, Hawaii County, and the Puna District (percentage of total acreage)

\begin{tabular}{lcccc}
\hline \multicolumn{1}{c}{ Place } & Agricultural & Conservation & Urban & Rural \\
\hline State of Hawaii & 47.9 & 47.8 & 4.0 & 0.3 \\
Hawaii County & 47.7 & 50.5 & 1.7 & 0.1 \\
Puna District & 54.6 & 43.6 & 1.7 & 0.1 \\
\hline
\end{tabular}

Source: Land Use Commission 1991.

Hawaii County and the Puna District: unused open space, agriculture, and recreation. In Hawaii County, unused open space accounts for approximately $56 \%$ of all land use, while agriculture accounts for $31 \%$ and recreation accounts for $10 \%$ (see Table 10). In the Puna District, unused open space is even more prevalent, comprising approximately $75 \%$ of all land use. Recreation $(16 \%)$ is the second largest land use in the Puna District, and agriculture (6\%) is third (County of Hawaii 1992b).

\section{ECONOMIC STRUCTURE}

Since the 1960 s, tourism has gradually replaced agriculture as Hawaii County's leading economic sector. As a result, the county's largest employment sectors are services $(29.9 \%$ of total 
ORNL-DWG 95-5959

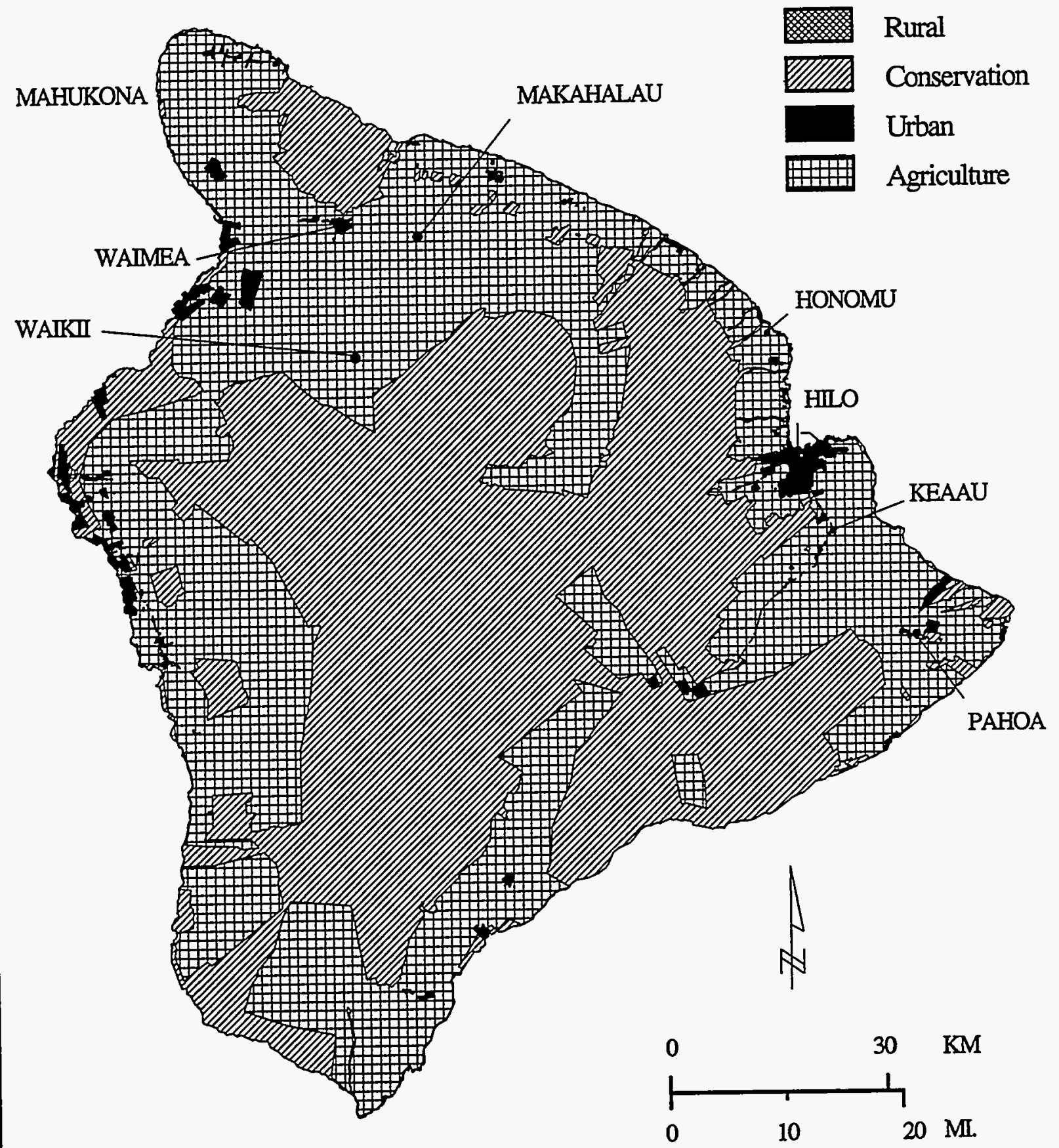

Fig. 2. State land use districts in Hawaii County. Source: Hawaii Office of State Planning Geographic Information System. 
Table 10. Land use by acreage and as a percentage of total:

Hawaii County and the Puna District

\begin{tabular}{lrr|rr}
\hline & \multicolumn{2}{c|}{ Hawaii County } & \multicolumn{2}{c}{ Puna District } \\
\cline { 2 - 5 } Land use & \multicolumn{2}{c|}{ Total } & \multicolumn{1}{c}{ Total } & acreage \\
\hline Unused open & $1,407,648$ & 56.1 & 237,277 & \% of total \\
space & 782,390 & 31.2 & 18,481 & 74.6 \\
Agricultural & 251,394 & 10.0 & 51,975 & 5.8 \\
Recreation & 32,661 & 1.3 & 170 & 16.3 \\
Services & 20,856 & 0.8 & 5,965 & 0.1 \\
Residential & 13,187 & 0.6 & 4,126 & 1.9 \\
All other & $2,508,136$ & 100.0 & 317,994 & 1.3 \\
\multicolumn{1}{c}{ Total } & & & & 100.0 \\
\hline
\end{tabular}

Source: County of Hawaii $1992 \mathrm{~b}$.

employment) and retail trade (18.4\%), followed by state and local government (12.9\%) and agriculture (8.6\%) (NPA 1993). Although agricultural employment has decreased, particularly with declines in the sugar industry, it still represents an important part of the county economy.

Agriculture continues to dominate the Puna District's economy. The district relies heavily on diversified agriculture (i.e., truck farming, papaya growing, and growing anthuriums and vanda orchids) for employment and income. Major employers in the Puna District include Amfac Tropical Products (papaya and guava processing), the Campbell Estate, the National Park Service, Kilauea Military Camp, Mauna Loa Macadamia Nuts, and Puna Geothermal Venture (County of Hawaii 1992a). Unlike other districts in Hawaii County, tourism plays a very small part in the Puna District's economy (County of Hawaii 1989).

In 1991, Hawaii County had a civilian labor force of 66,150 with 2646 (4.0\%) unemployed. This was higher than the state's unemployment rate (2.8\%), but lower than the U.S. rate (6.7\%) (NPA 1993). The Puna District had a civilian labor force of 6731 in 1990, of which 466 (6.9\%) were unemployed. The Puna District's 1990 unemployment rate was the highest of all the Hawaii County districts (County of Hawaii 1991).

In 1990, Hawaii County's total and per capita incomes, respectively, were $\$ 2.0$ billion and $\$ 16,728$, compared to $\$ 22.7$ billion and $\$ 20,361$ for the state (DBEDT 1993). In terms of per capita income, Hawaii County is the poorest in the state (DBEDT 1993). Incomes in the Puna 
District are generally lower than those in the rest of Hawaii County and the state (County of Hawaii 1992a).

\section{INFRASTRUCTURE AND PUBLIC SERVICES}

\subsection{EDUCATION}

Public education in Hawaii is provided by the State Department of Education, which is organized into seven districts. The Hawaii District, which serves Hawaii County, is further subdivided into several complexes. The Puna and Waiakea complexes serve the Puna District with eight schools. Table 11 provides data on current and projected (1995) enrollments for the schools in the Puna and Waiakea complexes. In addition, the table identifies schools where classroom shortages existed in 1992. In general, recent changes in school enrollment have reflected changes in area population.

In the Puna complex, Pahoa High and Elementary School experienced considerable growth during the 1980s and was well beyond its design capacity by the early 1990 s (Department of Education 1991c). Keonepoko Elementary (grades K-5) was opened in 1991 to help alleviate overcrowding, and another 10 classrooms are planned for Pahoa High and Elementary. These additions should be completed by 1996 (Hara 1993).

The Waiakea complex has also experienced steady growth in enrollment. Between 1986 and 1990, enrollment increased 14.6\% (Department of Education 1990b). Between 1990 and 1995, enrollment is projected to increase 10.4\% (Department of Education 1991a). This growth is largely due to the increased development of single-family residential areas near Keaau. In 1992, the Waiakea complex needed 53 classrooms to avoid overcrowding (Department of Education 1993). To address the problem, a new elementary school and a new high school are being planned. The former is in the site selection stage and may be completed by 1998; the latter is in the planning stage and may be completed by 2000 (Hara 1993).

To date, capacity problems have not affected school accreditation in the Puna and Waiakea complexes (Hara 1993). State law mandates that classes in grades K-2 not exceed a 20:1 student/teacher ratio. A union contract mandates that the student/teacher ratio in grades 3-12 not exceed 26:1. Staffing in the Hawaii District is maintained at or below these levels.

\subsection{GROUND TRANSPORTATION}

Hawaii County has approximately $2334 \mathrm{~km}$ (1450 miles) of roads, $2202 \mathrm{~km}$ (1368 miles) of which are paved (DBEDT 1991b). The county's major highway system is the Hawaii Belt Highway, which encircles the island (Fig. 3). The only four-lane divided highway on the island is state Route 11 between Keaau and Hilo (County of Hawaii 1989). 
Table 11. Public school enrollment, capacity, and projected enrollment in the Puna area

\begin{tabular}{|c|c|c|c|c|c|}
\hline School & $\begin{array}{c}1992 \\
\text { enrollment }\end{array}$ & $\begin{array}{c}1992 \\
\text { classrooms } \\
\text { required }\end{array}$ & $\begin{array}{c}\text { Net } \\
\text { classrooms } \\
\text { over/short, } \\
1992 \\
\end{array}$ & $\begin{array}{c}1995 \\
\text { enrollment } \\
\text { (projected) }\end{array}$ & $\begin{array}{l}\text { \% change in } \\
\text { enrollment } \\
(1990-95)\end{array}$ \\
\hline \multicolumn{6}{|c|}{ Puna Complex } \\
\hline $\begin{array}{l}\text { Keonepoko } \\
\text { Elem. }\end{array}$ & 585 & 31 & -3 & 710 & 59.2 \\
\hline $\begin{array}{l}\text { Pahoa } \\
\text { High/Elem. }\end{array}$ & 1438 & 86 & -9 & 1181 & -34.3 \\
\hline \multicolumn{6}{|c|}{ Waiakea Complex } \\
\hline $\begin{array}{l}\text { Keaau } \\
\text { Elem/Inter. }\end{array}$ & 1277 & 67 & -6 & 1476 & 20.7 \\
\hline $\begin{array}{l}\text { Mtn. View } \\
\text { Elem. }\end{array}$ & 799 & 43 & -9 & 816 & 13.5 \\
\hline Waiakea Elem. & 945 & 49 & -8 & 926 & -1.2 \\
\hline Waiakea High & 2146 & 105 & -19 & 2291 & 22.6 \\
\hline Waiakea Inter. & 1101 & 55 & -3 & 1049 & -2.0 \\
\hline $\begin{array}{l}\text { Waiakeawaena } \\
\text { Elem. }\end{array}$ & 989 & 48 & -8 & 970 & -3.1 \\
\hline
\end{tabular}

${ }^{a}$ Enrollment began at Keonepoko Elementary School in September 1991, when the first phase of the school opened. The second-phase classrooms were being completed and becoming available in 1992-93. The decline in enrollment at Pahoa High/Elementary is due to the transfer of students to the new elementary school.

Source: Department of Education 1993.

The Puna District has approximately $1112 \mathrm{~km}$ (691 miles) of roads, most of which are private roads in residential subdivisions. County [352 km (219 miles)] and state [76 km (47 miles)] roads constitute the rest of the district's road network. Many of the roads in the Puna District are considered substandard because of sharp curves, steep grades, inadequate drainage, narrow rightsof-way, and short sighting distances (County of Hawaii 1992a).

The most heavily traveled roads in the Puna District are state Route 11 from Hilo to the Hawaii Volcanoes National Park via Keaau, state Route 130 from Keaau to Kaimu via Pahoa, and state Route 137 from Kaimu to Kapoho. It is projected that traffic volume on Route 11 at 


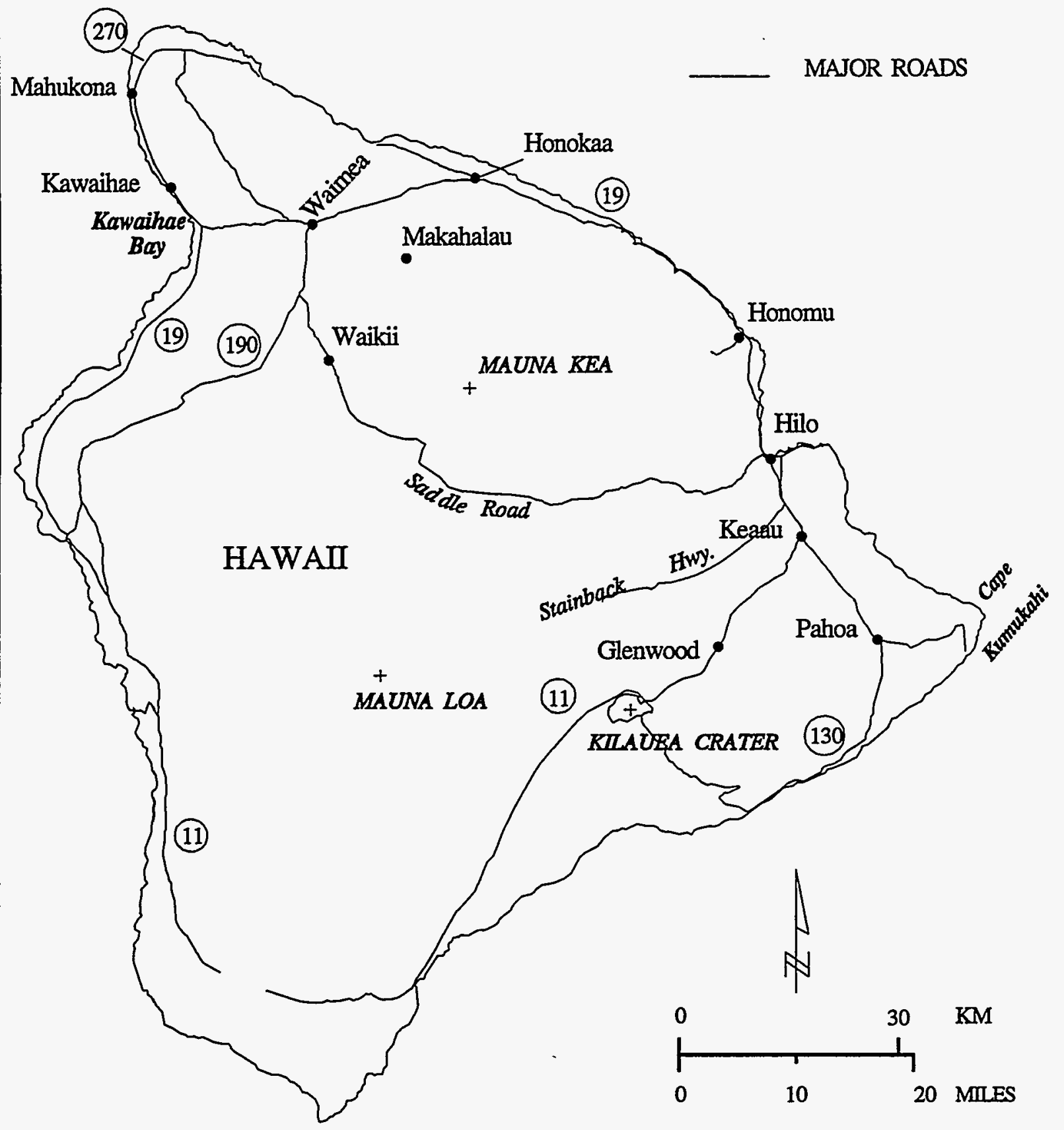

Fig. 3. Hawaii County: Major road segments. Source: Developed using information from the Hawaii Office of State Planning Geographic Information System. 
the South Hilo-Puna District boundary will increase from 19,000 vehicles per day in 1986 to 39,000 vehicles per day by 2010 . Route 130 at Keaau had a traffic volume of 10,398 vehicles per day in 1986 for a level of service (LOS) rating D. It is projected that traffic volume on the same segment will increase to 22,900 vehicles per day by 2010 , for a LOS rating F (gridlock) (County of Hawaii 1992a).

\subsection{POLICE AND FIRE PROTECTION}

The Hawaii County Police Department provides law enforcement services for the island. In the Puna District, 35 patrolmen and eight other officers stationed at Keaau serve a population of approximately 25,000 . Although response times have remained constant for several years, recent population growth has increased the need for law enforcement services countrywide. However, the county police department has no plans to add staff in the near future (Correa 1993).

The Hawaii County Fire Department provides fire protection services for the island. The Puna District is served by county fire department stations in Keaau and Pahoa. Service calls to the Puna District stations have increased in recent years to a high of 141 calls per month in 1992 (Yoshizumi 1993). Volunteer fire departments, trained by county personnel, respond to fire emergencies in the Paradise Park and Hawaiian Beaches subdivisions.

\subsection{WATER}

The Hawaii County Department of Water Supply had 30,848 service hookups that supplied 7356 million gallons of water during the year ending June 1991 (County of Hawaii 1991). Approximately 2250 (7.3\%) of the hookups were in the Puna District, and many of them supply more than one residence (County of Hawaii 1992).

The Department of Water Supply operates four separate water systems in the Puna District. The capacity and average draw of each system is provided in Table 12 . In addition, two private water systems serve about 1000 residences in the Hawaiian Beaches, Hawaiian Parks, Hawaiian Beach Terrace, and Hawaiian Park Terrace subdivisions.

Between 4000 and 5000 homes in the Puna District rely on individual roof-top catchment systems for their water supply. During periods of drought, water haulers provide service to residences that rely on catchment systems. However, the waiting period for water delivery was up to 30 days during the last drought (County of Hawaii 1992a).

\subsection{WASTEWATER}

There is no public sewer system in the Puna District. Evidence of contamination from existing cesspools in several parts of Hawaii County, including the Puna District, has led to the adoption of rules restricting the use of cesspools and encouraging the use of individual wastewater 
Table 12. County of Hawaii Department of Water Supply systems in the Puna District

\begin{tabular}{|c|c|c|c|}
\hline System & No. of wells & $\begin{array}{c}\text { Maximum } \\
\text { flow } \\
\text { capacity } \\
\text { (Mgd) }\end{array}$ & $\begin{array}{c}\text { Average } \\
\text { draw } \\
\text { (Mgd) }\end{array}$ \\
\hline Keaau-Mt. View & $3^{a}$ & 2.340 & 0.729 \\
\hline Pahoa & 3 & 1.872 & 0.426 \\
\hline Kapoho & $2^{a}$ & 0.144 & 0.065 \\
\hline Kalapana & 2 & 0.878 & 0.086 \\
\hline
\end{tabular}
capacity.

${ }^{a}$ One well is unused. Its potential capacity is not included in the maximum flow

Source: County of Hawaii 1992b.

systems (County of Hawaii 1992a). These new rules require individual wastewater systems on (1) all lots in the coastal area $300 \mathrm{~m}(1000 \mathrm{ft})$ from the shoreline or $30 \mathrm{~m}(100 \mathrm{ft})$ elevation, whichever is greater; (2) all lots smaller than one acre that are north of the east rift; and (3) all commercial developments that produce less than $3000 \mathrm{~L} /$ day $(800 \mathrm{gal} /$ day). Commercial developments producing more wastewater must have a sewage treatment plant (Ishi 1993).

\subsection{SOLID WASTE DISPOSAL}

The Solid Waste Division of the County of Hawaii Department of Public Works is responsible for solid waste disposal on the island, and currently operates two landfills. The division opened its new West Hawaii sanitary landfill, with a capacity of approximately 40 years, when it closed the old Kona landfill in October 1993. The county also plans to close its Hilo landfill, which is approaching capacity, after 1996. Plans for future waste disposal on the east side of the island are uncertain. Options being considered include constructing a transfer station at the Hilo landfill site and transporting waste to the West Hawaii landfill; developing a new east side landfill for all types of waste; or developing a new east side landfill for construction wastes only (Capellas 1994).

The Solid Waste Division also operates 21 solid waste transfer stations, five of which are in the Puna District. Hauling frequency from these stations to the Hilo landfill varies from every day to once a week. The average Puna District resident generates approximately 0.49 metric tons (0.54 short tons) of waste annually (Capellas 1994). 


\subsection{ELECTRICTTY}

Electricity rates in the state of Hawaii are among the highest in the United States because of the state's heavy reliance on imported oil for electrical generation and use of relatively small (and inefficient) power plants. The situation is even more extreme for the county of Hawaii, where the 1991 average residential rate $(\$ 0.139 / \mathrm{kWh})$ was about $32 \%$ higher than the average rate statewide (\$0.105/kWh) (DBEDT 1993). However, because the climate requires less heating and air conditioning than other parts of the U.S., average residential consumption of electricity in Hawaii $(7,252 \mathrm{kWh}$ ) is relatively low (DBEDT 1993). Hawaii County residential customers consume even less electricity, averaging about $6797 \mathrm{kWh}$ in 1991 (DBEDT 1993). Therefore, average residential energy costs are actually lower in the state than in many parts of the U.S. mainland. In 1990, Hawaii ranked 22nd out of the 50 states in per capita energy expenditures, with per capita expenditures of approximately $\$ 1973$ compared to the U.S. average of $\$ 1900$ (DBEDT 1993).

\subsection{EMERGENCY PLANNING}

Natural hazards in the Puna District, and especially around the Kilauea Volcano's east rift zone, include lava flows, earthquakes, tephra fallouts, tsunamis, and ground subsidence (Staub 1994). Severe storms, including occasional hurricanes, and floods also threaten island residents. Along the coast, offshore landslides are particularly hazardous because they can result in local tsunamis that can strike coastal residents without warning.

Because of the high potential for natural disasters on Hawaii (Heliker 1991), emergency planning is one of the more important services provided by Hawaii County. The islands are specially vulnerable because almost all goods and resources must be shipped or flown in. The isolation of the islands means a significant time delay if assistance is required from outside the state in the event of a disaster. Even on the island of Hawaii, delays in responding to emergencies occur because much of the island remains rural, and local emergency officials may not be able to provide sufficient response to a major event given the large numbers of non-english speaking tourists on the island each day.

The goal of emergency planning is to avoid or reduce the threat of harm to human health and safety, prevent the loss of property, and reduce adverse impacts on social activities so that recovery following an event can be promptly instigated. Emergency planning requires that the probability and potential consequences of threats or hazards be identified and the appropriate level of response be determined.

Planning for emergencies from volcanic eruptions on Hawaii has been and will continue to be, complicated by several factors (Community Management Associates, Inc. 1992). For example, lava flow characteristics are highly variable. Evacuation times for a volcanic eruption can vary between $24 \mathrm{~h}$ and several days, depending on the distance of a residence from the site of the eruption and the speed of the lava flow. Secondly, hazard zones are determined for large areas 
and are not site specific. Local topography, especially elevation, can significantly influence direction and speed of lava flows.

The perception of degree of risk from natural hazards also varies widely among parties at risk, often depending on the economic factors involved. Often, the highest hazard areas are often highly desirable places to live and visit. The Puna area, for example, offers an attractive rural lifestyle. Over 9000 potential homesites exist, under current zoning, in Lava Flow Hazard Zones 1 and 2 (presently classified as nonparticipating areas by the U.S. Department of Housing and Urban Development) and around the Kilauea east rift zone. Even with the threat of lava flows, earthquakes, and difficulty in obtaining home insurance, extensive housing development continues (Community Management Associates, Inc. 1992). The Hawaii County Civil Defense Agency (HCCDA) is responsible for directing and coordinating the county's emergency preparedness and response programs. Coordination between HCCDA and the U.S. Geological Survey has resulted in timely warnings, alerts, and evacuations in the areas affected by volcanic eruptions (FEMA 1990). In addition, public education programs provide residents with information on land subsidence and lava flow hazard zones and other hazards such as tsunamis and earthquakes. HCCDA's present warning system relies on mobile units for warning dissemination in rural areas.

Title III of the Superfund Amendments and Reauthorization Act of 1986 provides a mandate for industry and community cooperation for managing chemical hazards and outlines a structure for emergency preparedness for accidents involving hazardous materials (Fire, Grant, and Hoover 1990). The implementation of Title III requires states to establish a State Emergency Response Commission (SERC). The Hawaii Emergency Response Commission is chaired by the Director of the State Department of Health. Among the responsibilities of the SERC, after establishing planning districts, is the formation of local emergency planning committees (LEPCs). Each committee is expected to include elected state and local officials, fire, police, and public health officials, environmental advocates, hospital and transportation officials, representatives from facilities subject to emergency planning, community groups and the media. The function of the LEPC is to develop an effective plan to use if a hazardous material is released in the local community planning area (Fire, Grant, and Hoover 1990). The state of Hawaii has designated four counties to serve as local emergency planning districts-Oahu, Kauai, Maui, and Hawaii.

Emergency plans for geothermal development have been negotiated between the county of Hawaii and geothermal developers. For example, when the County of Hawaii Planning Commission initially approved (on August 8, 1989) a geothermal resource permit application (GRP89-1) from the University of Hawaii to drill Scientific Observation Holes (SOHs), one of the conditions was for the petitioner to present an emergency plan. The condition reads as follows:

Prior to any drilling activity, the petitioner shall submit, and secure approval from the Hawaii County Civil Defense Agency, a plan of action to deal with emergency situations which may threaten the health, safety, and welfare of the employees/persons in the vicinity of the proposed project. The plan shall include procedures to facilitate the coordination with appropriate state and county officials 
as well as the evacuation of affected individuals. The plan shall also include provisions for the applicant to provide alternate transportation for the areas affected in the event of a hazard associated with well drilling operations; for training the drill crews to handle emergencies; and to have available on site cement batching to plug the $\mathrm{SOH}$ in the event of an emergency.

Under this permit, emergencies are defined as events that could threaten or injure project personnel or individuals living or working near the project site "including volcanic activity, earthquakes, fire, severe storms, well blowouts, and other natural phenomena or unforeseen circumstance" (Hawaii Natural Energy Institute 1989).

A variety of factors need to be taken into account when determining the level of preparedness for emergencies. Previous experience with disasters and interorganizational relations are positively associated with success in disaster preparedness. The HCCDA has repeatedly responded to volcanic-related disasters in a timely and appropriate manner. Both the state of Hawaii and the county of Hawaii review and update their comprehensive disaster plans annually. In May 1990, the Governor of Hawaii and the Mayor of Hawaii County established a joint statecounty task force to address the long-term impacts of ongoing volcanic activity on residents and property owners in the Kalapana Region of Hawaii (FEMA 1990).

\section{LOCAL GOVERNMENT REVENUES AND EXPENDITURES}

In the state of Hawaii, there are no municipal or local governments below the county level (although the city and county of Honolulu have a combined city-county government). Thus, local government services on Hawaii are provided by the county rather than towns within the county.

More than $80 \%$ of Hawaii County's tax revenue (and about 53\% of the county's total revenue) is derived from taxes on real property (Table 13). The county's real property tax rate for industrial developments is $\$ 10$ per $\$ 1000$ net taxable value of the land, and $\$ 8.50$ per $\$ 1000$ net taxable value of the buildings. The county also generates revenue through a liquid fuel tax, a motor vehicle weight tax, and the public utility franchise tax (a tax applied to electric and gas utilities, which are exempt from general excise and property taxes). Other major sources of county revenue include state and federal grants, departmental earnings and charges, and fees, licenses, permits and fines (County of Hawaii 1991).

Approximately $40 \%$ of the county's expenditures are for public safety, largely police and fire protection. Other major expenditure categories include general government, recreation, highways, and pension and retirement funds (County of Hawaii 1991). 
Table 13. Hawaii County operating revenues and expenditures, FY 1990

\begin{tabular}{|c|c|c|}
\hline Subject & $\begin{array}{l}\text { Reveniues/ } \\
\text { expenditures } \\
\text { (thousands) }\end{array}$ & $\begin{array}{c}\% \\
\text { of total }\end{array}$ \\
\hline Total operating revenues & 96,501 & 100.0 \\
\hline Real property taxes & 51,652 & 53.5 \\
\hline Other taxes & 9,156 & 9.5 \\
\hline Fees, licenses, permits, and fines & 3,218 & 3.3 \\
\hline Departmental earnings and charges & 5,904 & 6.1 \\
\hline State grants & 21,109 & 21.9 \\
\hline Federal grants & 3,895 & 4.0 \\
\hline Other sources & 1,567 & 1.6 \\
\hline Total operating expenditures & 88,471 & 100.0 \\
\hline General government & 12,649 & 14.3 \\
\hline Public safety & 36,100 & 40.8 \\
\hline Highways & 6,009 & 6.8 \\
\hline Health and sanitation & 4,851 & 5.5 \\
\hline Public welfare & 3,305 & 3.7 \\
\hline Public schools & 250 & 0.3 \\
\hline Recreation & 7,219 & 8.2 \\
\hline Interest & 5,083 & 5.7 \\
\hline Bond redemption & 3,022 & 3.4 \\
\hline Pension and retirement & 5,969 & 6.7 \\
\hline Mass transit & 490 & 0.6 \\
\hline Miscellaneous & 2,457 & 2.8 \\
\hline Cash capital improvements & 1,067 & 1.2 \\
\hline
\end{tabular}

Source: County of Hawaii 1991. 


\section{TOURISM AND RECREATION}

Although the island of Hawaii does not attract as many tourist visits as other parts of the state, tourism does represent a major component of Hawaii County's economy and thus has direct and indirect effects on population, housing, land use, and the provision of public services. In 1990, Hawaii County had an average of 16,970 visitors per day compared to 87,400 for the city and county of Honolulu, 39,500 for Maui County, and 18,200 for Kauai County. Most tourists visiting the county (approximately $88 \%$ in 1990) visit the Kona area on the island's western coast. Hilo is the second most popular area in the county, visited by approximately $33 \%$ of all tourists. It is estimated that visitors generated over $\$ 925$ million for the county's economy in 1990 , and that visitors from the U.S. mainland and Japan spent approximately $\$ 136$ and $\$ 294$ per day, respectively (County of Hawaii 1992b).

Hawaii County had 92 visitor properties (i.e., hotels, apartment hotels, cottages, bed and breakfasts, and condominium units for transient use) with a total of 8952 units in 1990. The average occupancy rate for these units was $62 \%$ for the county, $66.8 \%$ for the Kona area, and $59.3 \%$ for the Hilo area. Hotel employment provided an annual average of 6277 jobs and a total payroll of nearly $\$ 110$ million for county residents in 1990 (County of Hawaii 1991).

Tourism plays a smaller role in the Puna District's economy than it does in other parts of the county. Puna's tourism industry consists primarily of small bed and breakfast accommodations in Volcano. The number of bed and breakfast units in Volcano grew from one in 1985 to 50 in 1990. The rest of the Puna District has about 20 rooms available in a variety of small-scale and bed and breakfast visitor units (County of Hawaii 1992a).

It is likely that future trends in tourism in Hawaii County will reflect those of the state. In the three-year period from 1991 through 1993, the number of visitors staying overnight or longer in the state declined each year, for a total decrease of $12.3 \%$ (855,880 visitors) from the 1990 level (DBEDT 1993; Hawaii Visitors Bureau 1994). This represents only the third multi-year decrease in the number of visitors staying overnight or longer since 1921; other multi-year decreases occurred from 1930 through 1933 during the Great Depression, and from 1942 through 1945 during World War II (DBED 1988; DBEDT 1993).

Hawaii County has many recreational opportunities for visitors and residents. The county has four national parks [93,329 ha (230,621 acres)], 19 state parks (including state monuments, recreation areas, and historical parks) [550 ha (1359 acres)], and 113 county parks [379 ha (789 acres)]. Approximately 25,700 ha (63,500 acres) of the Hawaii Volcanoes National Park are located within the Puna District. However, because lava has covered the road at Kalapana, the only vehicular access to the park is in the Ka'u District. The state provides three recreational properties within the Puna District, the MacKenzie State Recreation Area [7.9 ha (19.5 acres)], the Kilauea State Recreation Area [ 3 ha (7.3 acres)], and the Lava Tree State Monument [ 6.9 ha (17 acres)]. The county provides 15 recreational sites within the Puna District. However, two of the district's larger county beach parks, the Harry K. Brown Park and the Kalapana/Kaimu Beach Park, were covered by lava in 1990 (County of Hawaii 1991, 1992a). 
Hawaii County's Park Dedication Ordinance (No. 333 of December 1977) requires that 2 ha ( 5 acres) of park be established for every 1000 residents. This ordinance has not, however, been strictly enforced on a district-by-district basis (County of Hawaii 1992a). The Puna District has a total of 50.3 ha (124.2 acres) of state and county parks, but less than half the acreage has been developed. Thus, the Puna District does not have enough developed recreation space to meet the needs of its residents (County of Hawaii 1992a).

The state's 1990 State Recreation Functional Plan (DLNR 1990) identifies four specific action programs for the Puna District:

- address the shortage of beach parks in the district;

- develop soccer fields, a gymnasium, and other community-based recreation facilities to serve the Kea'au-Pahoa area;

- develop tennis courts and other active recreation facilities at Pahoa Park, Volcano Playground, and Opihi Kao Playground; and

- implement planned county bikeways such as Kea'au-Pahoa Route 130, Kea'au-Hilo Route 11, and Volcano-Kea'au. Implement state bikeways such as Pahoa-Kapoho Route 132.

According to a 1992 study conducted for the County of Hawaii Planning Department, there is a shortage of beach parks and other ocean-oriented recreation areas in the Puna District (County of Hawaii 1992a). Since the Harry K. Brown Park and the Kalapana/Kaimu Beach Park have been covered by lava, the county has only one beach park, the 0.73-ha (1.79-acre) Isaac Hale Beach Park. The county owns two other beach parks, the Hawaiian Beaches Shoreline Park [1.45 ha (3.58 acres)] and the Hawaiian Paradise Park [2.44 ha (6.03 acres)], but neither of these properties has been developed. The only other beach park in the Puna District is the MacKenzie State Park, which has 2.8 developed ha (6.8 acres) (County of Hawaii 1992a).

\section{REFERENCES}

Capellas, L. 1994. Solid Waste Division, Hawaii County Department of Public Works, Hilo, Hawaii, personal communication with James W. Saulsbury, Oak Ridge National Laboratory, Oak Ridge, Tenn. (January).

Community Management Associates, Inc. 1992. Puna Community Development Plan, Technical Reference Report prepared for the County of Hawaii Planning Department, Hilo, Hawaii (January 15).

Correa, J. 1993. Hawaii County Police Department, Hilo, Hawaii, personal communication with James W. Saulsbury, Oak Ridge National Laboratory, Oak Ridge, Tenn. (September). 
County of Hawaii. 1988. Population and Economic Projections for the State of Hawaii to 2010.

Series $M-K$, County of Hawaii Department of Research and Development, Research and Economic Analysis Division, Hilo, Hawaii (November).

County of Hawaii. 1989. The General Plan: Hawaii County, the Council of the County of Hawaii, Hilo, Hawaii (November).

County of Hawaii. 1991. Data Book 1991, County of Hawaii Department of Research and Development, Hilo, Hawaii (December).

County of Hawaii. 1992a. Puna Community Development Plan Technical Reference Report, prepared by Community Management Associates, Inc., for the County of Hawaii Planning Department, Hilo, Hawaii (January 15).

County of Hawaii. 1992b. Data Book 1992, County of Hawaii Department of Research and Development, Hilo, Hawaii (December).

DBED (Department of Business and Economic Development). 1988. The State of Hawaii Data Book 1987, Honolulu.

DBEDT (Department of Business, Economic Development and Tourism). 1991a. The Population of Hawaii, 1990, Statistical Report 219, Research and Economic Analysis Division, Statistics Branch, Honolulu (July).

DBEDT (Department of Business, Economic Development and Tourism). 1991b. The State of Hawaii Data Book 1991--A Statistical Abstract, Research and Economic Analysis Division, Statistics Branch, Honolulu (November).

DBEDT (Department of Business, Economic Development and Tourism). 1993. Data Book 1991A Statistical Abstract, Research and Economic Analysis Division, Statistics Branch, Honolulu (March).

Department of Education. 1991a. Enrollment Projections of the Public Schools in Hawaii, 19911996, State of Hawaii, Department of Education, Honolulu (May).

Department of Education. 1991b. Waiakea Complex Development Plan: 1990-2010. State of Hawaii, Department of Education, Hawaii District, Hilo, Hawaii (September).

Department of Education. 1991c. Pahoa Complex Development Plan: 1990-2010, State of Hawaii, Department of Education, Hawaii District, Hilo, Hawaii (April). 
Department of Education. 1993. State Classroom Utilization Report Summary: School Year 19921993, State of Hawaii, Department of Education, Department of Business Services, Facilities Branch, Honolulu (March).

DLNR (Department of Land and Natural Resources). 1990. State Recreation Functional Plan Technical Reference Document and State Comprehensive Outdoor Recreation Plan (SCORP), Honolulu.

FEMA (Federal Emergency Management Agency). 1990. Hazard Mitigation Team Report for Kilauea Volcano Eruption, Hawaii County, Hawaii, FEMA-864-DR-HI, Honolulu.

Fire, F. L., N. K Grant, and D. H. Hoover. 1990. SARA Title III: Intent and Implementation of Hazardous Materials Regulations, Van Nostrand Reinhold, New York.

Gigliotti, R. and R. Jason. 1991. Emergency Planning for Maximum Protection. ButterworthHeiemann, Stoneham, Mass.

Hara, H. 1993. Business Specialist, Hawaii District Office, State Department of Education, Hilo, Hawaii, personal communication with Susan M. Schexnayder, Oak Ridge National Laboratory, Oak Ridge, Tenn. (June 16).

Hawaii Natural Energy Institute. 1989. Emergency Plan, Scientific Observation Hole (SOH) Program, Geothermal Resource Permit: GRP 89-1; Lilewa, Kapoho, and Halekamahina, Hawaii, TMK: 1-2-10:01; and 1-4-02:32, University of Hawaii at Manoa, Honolulu (September).

Hawaii Visitors Bureau. 1994. Research Staff Member, personal communication with J. W. Saulsbury, Oak Ridge National Laboratory, Oak Ridge, Tenn. (March 28).

Heliker, C. 1991. Volcanic and Seismic Hazards on the Island of Hawaii, U.S. Geological Service General Interest Publication, Washington, D.C.

Ishi, B. 1993. Wastewater Division of Hawaii County Department of Public Works, Hilo, Hawaii, personal communication with Susan M. Schexnayder, Oak Ridge National Laboratory, Oak Ridge, Tenn. (June 18).

Land Use Commission. 1991. The State of Hawaii Land Use Law: A Summary, State of Hawaii, . Honolulu. 
NPA (National Planning Association). 1993. Economic/Household Printouts [Computer printouts from NPA Data Services containing historical and projected economic and demographic data for the County of Hawaii] (February 1).

Staub, W. P. 1995. Environmental Resources of Selected Areas of Hawaii: Geological Hazards, ORNL/TM-12857, Oak Ridge National Laboratory, Oak Ridge, Tenn.

U.S. Bureau of the Census. 1978. County and City Data Book, 1978, Washington, D.C.

U.S. Bureau of the Census. 1988. County and City Data Book, 1988, Washington, D.C.

U.S. Bureau of the Census. 1992. Summary Tape File 1A. [CD Rom], Washington, D.C., 1992.

Yoshizumi, R. 1993. Hawaii County Fire Department, Hilo, Hawaii, personal communication with James W. Saulsbury, Oak Ridge National Laboratory, Oak Ridge, Tenn. (September 29). 


\section{LIST OF PREPARERS}

\section{Oak Ridge National Laboratory}

Robert M. Reed, Research Staff, Energy Division

Contribution: Project management and review

Education: Ph.D. Plant Ecology, Washington State University

James W. Saulsbury, Research Staff, Energy Division

Contribution: Socioeconomics and assistant project manager

Education: M.S. Planning, 1989, University of Tennessee-Knoxville

Barbara M. Sorensen, Research Staff, Energy Division

Contribution: Emergency planning

Education: Ph.D., Sociology, 1988, University of Tennessee-Knoxville

\section{Consultant}

The following individual prepared contributions as indicated under subcontract with Oak Ridge National Laboratory:

Susan M. Schexnayder

Technical contribution: Socioeconomics

Education: M.A., Anthropology, 1994, Louisiana State University

Professional affiliation: Environment, Energy, and Resource Center, University of Tennessee-Knoxville 


\section{INTERNAL DISTRIBUTION}

1. T. J. Blasing

2. G. E. Courville

3. C. E. Easterly

4. F. M. Glenn

5. D. A. Lombardi

6. C. H. Petrich

7. H. D. Quarles, III

8-17. R. M. Reed

18. D. E. Reichle

19. J. W. Saulsbury

20. A. C. Schaffhauser
21. S. M. Schexnayder

22. R. B. Shelton

23. B. M. Sorensen

24. W. P. Staub

25. V. R. Tolbert

26. A. K. Wolfe

27-28. Laboratory Records

29. Laboratory Records-RC

30. Document Reference Section

31. Central Research Library

32. ORNL Patent Section

\section{EXTERNAL DISTRIBUTION}

33. Office of the Assistant Manager for Energy Research and Development, Department of Energy, Oak Ridge Operations, P. O. Box 2001, Oak Ridge, TN 37831

34. Andrea Campbell, Department of Energy, Oak Ridge Operations, Bldg. 2714-J, SE-311, Oak Ridge, TN 37831-8739

35. Virginia H. Goldstein, Director, Hawaii County Planning Commission, 25 Aupuni Street, Room 109, Hilo, HI 96721

36. Charles B. Hamilton, 9023 Fox Lonas Road, Knoxville, TN 37923

37. Hugo Huntzinger, Superintendent, Hawaii Volcanoes National Park, P. O. Box 52, Hawaii Volcanoes National Park, HI 96718-0052

38. Maurice H. Kaya, Energy Program Administrator, Department of Business, Economic Development \& Tourism, 335 Merchant Street, Suite 108, Honolulu, HI 96813

39. Allan J. Jelacic, Office of Renewable Energy Conversion (EE-12), U.S. Department of Energy, Forrestal Building, 1000 Independence Ave. SW, Washington, DC 20585

40-44. Roland R. Kessler, Director, Office of Renewable Energy Conversion (EE-12), U.S. Department of Energy, Forrestal Building, 1000 Independence Ave. SW, Washington, DC 20585

45. Mike Lee, Chief, Operations Division, Honolulu Engineer District, Building 230, Fort Shafter, HI 96858-5440 
46. John Naughton, Pacific Area Office, National Marine Fisheries Service, National Oceanic and Atmospheric Administration, 2570 Dole Street, Honolulu, HI 96822-2396

47. Manuel Nathenson, U.S. Geological Survey, Geologic Division, Branch of Volcanic and Geothermal Processes, 345 Middlefield Road, M/S 910, Menlo Park, CA 94025

48. Robert Smith, Director, Pacific Island Office, U.S. Fish and Wildlife Service, Prince Kuhio Building, Room 6307, 300 Ala Moana Boulevard, Honolulu, HI 96850

49-53. Judith C. Stroud, ER-10, Department of Energy, Oak Ridge Operations Office, P. O. Box 2001, Oak Ridge, TN 37831-6600

54. Carl C. Trettin, Center for Forested Wetland Research, Southeastern Forest Experiment Station, 2730 Savannah Highway, Charleston, SC 29414

55. Lillian D. Trettin, 712 Wakendaw Blvd., Mount Pleasant, South Carolina 29464

56-57. Office of Scientific and Technical Information, P. O. Box 62, Oak Ridge, TN 37831 